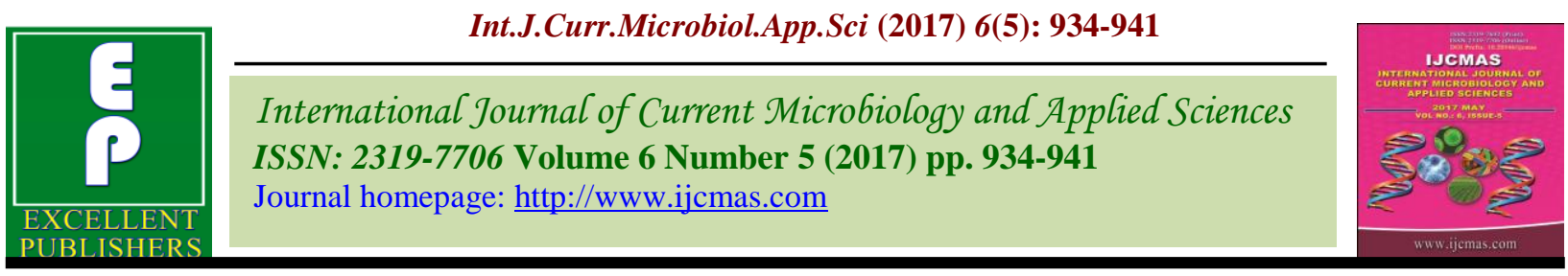

Original Research Article

https://doi.org/10.20546/ijcmas.2017.605.103

\title{
Economics of OBM Gill Netters along the Jaleshwar Coast, Veraval, Gujarat, India
}

\author{
Shabir Ahmad Dar ${ }^{*}$, A.Y. Desai ${ }^{2}$, A.N. Sayani ${ }^{2}$ and Jyoti Sharma ${ }^{3}$ \\ ${ }^{1}$ Government Degree college Baramulla, Jammu and Kashmir, India-193 103 \\ ${ }^{2}$ College of Fisheries Junagadh Agricultural University, Veraval, Gujarat- 362 265, India \\ ${ }^{3}$ Government Degree college Kathua, Jammu and Kashmir, India- 184101 \\ *Corresponding author
}

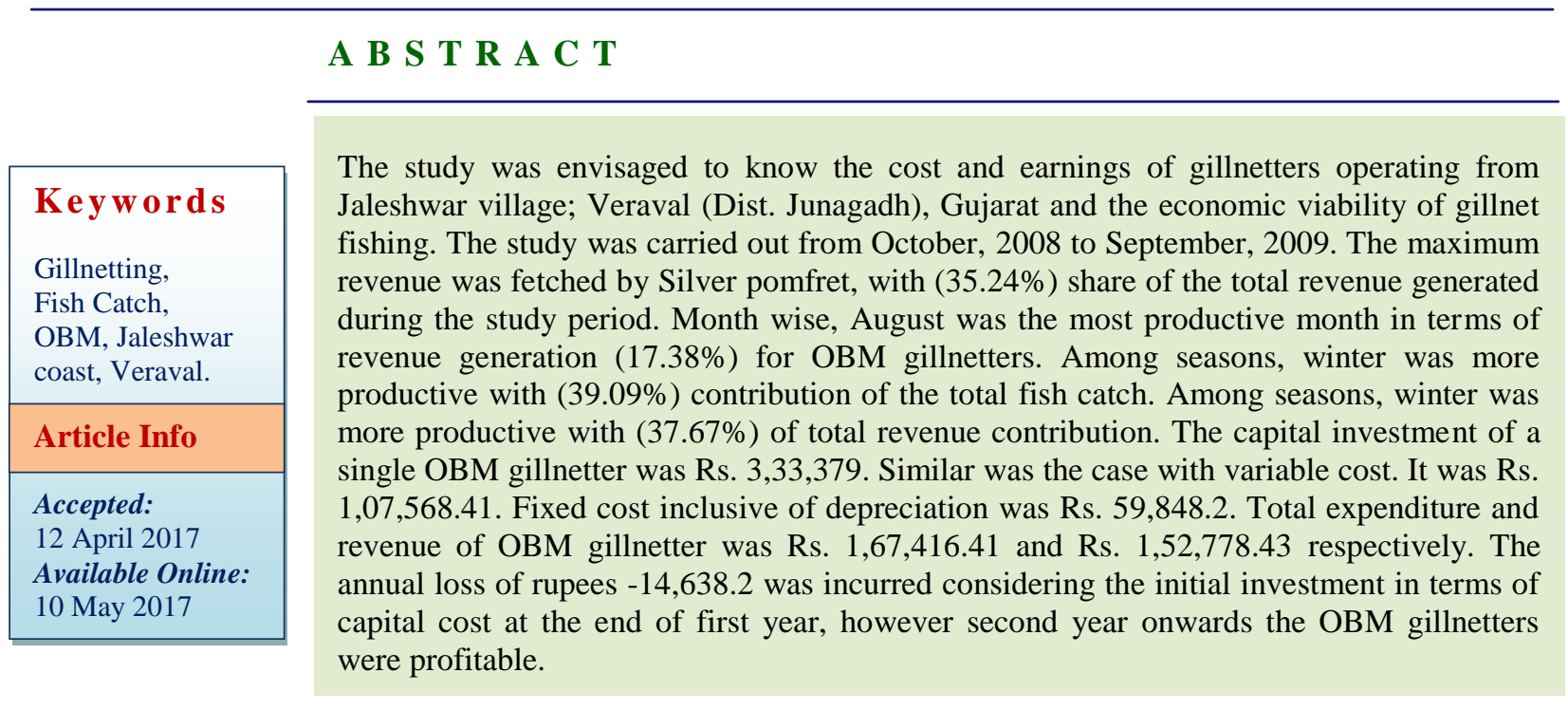

\section{Introduction}

Gillnet is a highly selective fishing gear and is one of the most suitable fish catching method from conservation and stock regulation point of view (Thomas, 2003). Gujarat is a frontline maritime state of India located in the extreme west of the country $\left(20.1^{\circ}\right.$ to $24.7^{\circ}$ North and $68.4^{\circ}$ to $74.4^{\circ}$ East). Gujarat with about $20 \%$ $(1600 \mathrm{~km})$ of the country's coastline, $33 \%$ of the continental shelf area $\left(1,64,000 \mathrm{~km}^{2}\right)$ and over 2, 00,000 $\mathrm{km}^{2}$ of EEZ ranks first among the maritime states in marine capture fish production $^{1}$. Gujarat with about $20 \%$ of the country's coastline (1600 kms.), 33\% of the continental shelf area $\left(1,64,000 \mathrm{~km}^{2}\right)$ and over 2, 00,000 $\mathrm{km}^{2}$ of EEZ (Exclusive economic zone) ranks first among the maritime states in marine capture fish production with 7.17 lakh tonnes (CMFRI, 2014).

Out Board gillnetters play an important role as it contribute about $15.83 \%$ overall fish production in Gujarat. There has been continuous increase in the number of mechanized boats in the fishing fleet of state since last decade. Presently, more than 31,370 boats are active in fishing operation, out of which more than 20,359 are mechanized boats and 2,316 are gillnetters operating in coastal waters of Gujarat (Anon., 2009). 
Jaleshwar village is located between Lat$20^{\circ} 54^{\prime} \mathrm{N}$ and Lon- $79^{\circ} 22^{\prime} \mathrm{E}$, which is $4 \mathrm{~km}$ far from the main fishing port of Veraval. There are160 FRP (Fibre Reinforced Plastic) canoes in the Jaleshwar village, out of which only 60 are active in fishing. Most of the population of this village depends upon fishing activities as the main source of occuption (Anon., 2009). The fishermen of Jaleshwar operate only gillnet throughout the year. The most notable fact about Jaleshwar village is that it was first village in the Gujarat state where motorized boats were first operated (Somashekar et al., 2003). The objective of the present study was to estimate cost and earnings of gillnetters operating off Jaleshwar Coast, Veraval.

\section{Materials and Methods}

The present work was undertaken to study the cost and earnings of the gillnetters operating gillnet along the of Jaleshwar coast Veraval. The study was carried out for a period of one year from October 2008 to September 2009. Total 60 OBM gillnetters were randomly sampled. The periodical random sampling method was adopted for sampling of gillnetters as per (Marked, 2004). Economic analysis was done by calculating capital cost, total variable cost, total project cost, total fixed cost, total cost, total revenue, and finally annual profit was calculated as per the Markad (2004).

Total revenue will be calculated after personal inquiring of prices of fish per kilogram at the landing centre and multiplying it with the quantity of catch landed by a gillnetter.. The data obtained for all the weeks in the month was pooled and presented as monthly samples. The data was also analysed season wise viz. June to September (Monsoon season), October to January (winter season) and February to May (summer season) to know the dominant cost and earnings over different months and season. The results are expressed as mean \pm std. error for all the collected data.

\section{Results and Discussion}

The total catch composition of the gill nets was $236.36 \mathrm{~kg}$. on an average during eleven months, the paper was published by author in International Journal of Ecology Environment and Conservation 20 (Suppl.): 2014; pp. (S39S43).

Details of species wise revenue according to month from October 2008 to September 2009 are given in table 1 . The revenue generated from 14 different fish varieties landed by OBM gillnetters along Jaleshwar coast, Veraval, showed that the Silver pomfret contributed maximum revenue (35.24\%) among all groups. This was followed by other Indian mackeral (25.49\%), Ribbon fish (16.84\%), Hilsa (12.09\%), Wolf herring (3.28\%), Croaker (2.64\%), Lesser sardine $(1.32 \%)$, Seer fish (1.13\%), Horse mackeral (1.05\%), Catfishes (0.38\%), Eel (0.26\%), Other horse mackerel $(0.15 \%)$, Barracuda $(0.09 \%)$ and Black pomfret $(0.03 \%)$. Minimum revenue was recorded during June, 2009 (4.04\%). In August, 2009 maximum revenue was generated $(17.38 \%)$. Out of two groups, pelagic fishes shared $(61.44 \%)$, and demersal fishes $(38.56 \%)$ of the total revenue. Revenue was found high in August, 2009 (17.38\%) followed by September, 2009 (15.52\%). Month of October, 2008 contributed $(10.34 \%)$ revenue, but in November, 2008 revenue slightly increased to (12.11\%). In the month of December, 2008 revenue drastically decreased $(6.45 \%)$; however in the month of January, 2009 there was a slight increase in the revenue $(8.78 \%)$. Revenue again decreased (5.92\%) in February, 2009, but in the case of March, 2009 , the revenue slightly increased $(7.66 \%)$. The revenue in April, 2009, was (4.71\%). In 
May, 2009 it increased to (7.10\%), but again the revenue decreased in the month of June, 2009 (4.04\%). Sehara and Karbhari (1989a) studied catch composition of mechanised gillnetters operated along the Maharashtra coast and reported almost similar results. Authors reported October as the most productive month at Khar-Danda and Satpati. Further they reported that pomfret and seerfish were the major species which generated the maximum revenue. Markad (2004) reported that revenue fetched by Indian mackerel was maximum with $45.97 \%$ in case of OBM gillnetter whereas seerfish generated the maximum revenue $(71.15 \%)$ for IBM gillnetters.

The species wise revenue according to season is presented in table 2. The winter was most productive with contribution of $(37.67 \%)$, followed by Monsoon (36.93\%) and summer $(25.39 \%)$. Indian mackerel in winter shared total revenue $(26.83 \%)$, summer $(40.34 \%)$ and in monsoon month Silver pomfret produced maximum revenue $(35.24 \%)$. The comparison between different seasons gave an idea of share of Indian mackerel in seasonal revenue which was highest in summer $(44.41 \%)$ and lowest in monsoon $(40.65 \%)$. Similar findings were also reported by Sehara and Karbhari (1989a) at selected centres along the Maharashtra coast. They reported that the post-monsoon quarter (SeptemberNovember) were most productive with the seerfish as maximum contributor to gill net fishing. Silas et al. (1984) reported April and July to October months as more productive in the year 1981 and the productive months during the year 1982 were April, May and July-October. Sathiadhas and Panikkar (1988) reported monsoon as the most productive season along the Trivendrum coast, whereas, Koya and Vivekanandan (1992) reported maximum landings in the September. Markad, (2004) reported peak landings along Ratnagiri coast in the October month.

\section{Economics}

Economic analysis was carried out for OBM gillnetter units. Capital cost, variable cost, fixed cost, total expenditure, revenue and net profit were the major components considered for economic analysis. The economic analysis is shown in table 3 .

\section{Capital cost}

Cost of vessel, cost of engine, cost of net and other miscellaneous items with more than one year life span were included to calculate the average capital cost of a gillnetter. The capital investment was Rs. 3,33,379 for OBM gillnetters. In OBM unit, engine cost alone contributed $23.43 \%$ of the total capital cost. Vessel cost of OBM was $22.40 \%$. Net cost contributed $46.51 \%$. In case of gear accessories (rope, buoys, floats, anchor and sinkers) cost, which shared $7.66 \%$ for OBM respectively. (Sathiadhas et al., 1991), Rs. 10,000 to Rs. 50,000for in West Bengal during year 1983-84 (Datta and Dan, 1992), Rs. 25,400 and Rs. 52,480 for motorised catamarans and motorised navas in Kanyakumari district of Tamil Nadu State (Annamalai and Kandoran, 1993), Rs. $1,05,000$ to Rs. $1,23,000$ for the gillnetters operated from Cochin fishing harbour during the year 1990 (Iyer, 1993) and Rs. 58,000 and Rs. 1,60,00 for the gillnetters operated from Kerala (Panikkar et al., 1993), Rs. 3,01,000 to Rs. 4,00,000 for gillnetters operated along Chennai coast during 1991-92 (Luther et al., 1997) and Rs. 1,48,414 for OBM gillnetters (Markad, 2004).

During the present study, the capital cost of OBM gillnetter was high as compared to many authors Markad, (2004). The difference in capital cost recorded on higher side in the present study may be attributed the increase in price of raw material. 
Table.1 Details of species wise mean fish landings (kg) of OBM gillnetters from October 2008 to September 2009

\begin{tabular}{|c|c|c|c|c|c|c|c|c|c|c|c|c|c|c|}
\hline $\begin{array}{l}\text { Sr. } \\
\text { No. }\end{array}$ & SPECIES & Oct, 2008 & Nov, 2008 & $\begin{array}{l}\text { Dec, } \\
2008 \\
\end{array}$ & Jan, 2009 & $\begin{array}{l}\text { Feb, } \\
2009\end{array}$ & $\begin{array}{l}\text { Mar, } \\
2009 \\
\end{array}$ & $\begin{array}{l}\text { Apr, } \\
2009\end{array}$ & $\begin{array}{l}\text { May, } \\
2009 \\
\end{array}$ & $\begin{array}{l}\text { June, } \\
2009\end{array}$ & \begin{tabular}{|l} 
July, \\
2009 \\
\end{tabular} & \begin{tabular}{|l} 
Aug, \\
2009
\end{tabular} & $\begin{array}{l}\text { Sept, } \\
2009 \\
\end{array}$ & Total \\
\hline \multicolumn{11}{|c|}{ Pelagic fishes } & \multirow{10}{*}{$\begin{array}{l}\text { No catch } \\
\text { due to } \\
\text { Monsoon } \\
\text { ban }\end{array}$} & & & \\
\hline 1 & Lepturacanthus savala & $\begin{array}{c}2.85 \\
( \pm 0.46)\end{array}$ & $\begin{array}{c}4.38 \\
( \pm 0.56)\end{array}$ & $\begin{array}{c}2.58 \\
( \pm 0.51)\end{array}$ & $\begin{array}{c}1.74 \\
( \pm 0.37)\end{array}$ & $\begin{array}{c}2.22 \\
( \pm 0.43)\end{array}$ & $\begin{array}{c}4.58 \\
( \pm 0.67)\end{array}$ & $\begin{array}{c}1.7 \\
( \pm 0.37)\end{array}$ & $\begin{array}{c}2.7 \\
( \pm 0.43)\end{array}$ & $\begin{array}{c}4.17 \\
( \pm 0.95)\end{array}$ & & $\begin{array}{c}4.1 \\
( \pm 0.68)\end{array}$ & $\begin{array}{c}5.2 \\
( \pm 0.73)\end{array}$ & 36.22 \\
\hline 2 & Scomberomorus commerson & $\begin{array}{c}0.2 \\
( \pm 0.14) \\
\end{array}$ & 0 & 0 & $\begin{array}{c}0.67 \\
( \pm 0.13) \\
\end{array}$ & $\begin{array}{c}0.19 \\
( \pm 0.13) \\
\end{array}$ & 0 & 0 & 0 & 0 & & 0 & $\begin{array}{c}0.02 \\
( \pm 0.02) \\
\end{array}$ & 1.08 \\
\hline 3 & Rastrelilliger Kanagurta & $\begin{array}{c}10.05 \\
( \pm 1.21) \\
\end{array}$ & $\begin{array}{c}12.9 \\
( \pm 0.88)\end{array}$ & $\begin{array}{c}12.62 \\
( \pm 1.17)\end{array}$ & $\begin{array}{c}3.65 \\
( \pm 0.63) \\
\end{array}$ & $\begin{array}{c}6.24 \\
( \pm 1.06) \\
\end{array}$ & $\begin{array}{c}11.84 \\
( \pm 0.89) \\
\end{array}$ & $\begin{array}{c}9.65 \\
( \pm 0.88) \\
\end{array}$ & $\begin{array}{c}12.67 \\
( \pm 1.03) \\
\end{array}$ & $\begin{array}{c}14.78 \\
( \pm 1.81) \\
\end{array}$ & & $\begin{array}{c}3.04 \\
( \pm 0.44) \\
\end{array}$ & $\begin{array}{c}12.17 \\
( \pm 1.15) \\
\end{array}$ & 109.6 \\
\hline 4 & Megalalapsis cordyla) & $\begin{array}{c}3.48 \\
( \pm 0.76) \\
\end{array}$ & $\begin{array}{c}0.68 \\
( \pm 0.17) \\
\end{array}$ & $\begin{array}{c}0.03 \\
( \pm 0.03) \\
\end{array}$ & $\begin{array}{c}2.93 \\
( \pm 1.01) \\
\end{array}$ & $\begin{array}{c}1.67 \\
( \pm 0.33) \\
\end{array}$ & $\begin{array}{c}0.66 \\
( \pm 0.18) \\
\end{array}$ & $\begin{array}{c}0.07 \\
( \pm 0.05) \\
\end{array}$ & $\begin{array}{c}0.03 \\
( \pm 0.02) \\
\end{array}$ & $\begin{array}{c}0.34 \\
( \pm 0.16) \\
\end{array}$ & & 0 & $\begin{array}{c}0.77 \\
( \pm 0.22) \\
\end{array}$ & 10.66 \\
\hline 5 & Hilsa toli & $\begin{array}{c}1.9 \\
( \pm 0.34)\end{array}$ & $\begin{array}{c}2.58 \\
( \pm 0.33) \\
\end{array}$ & $\begin{array}{c}1.99 \\
( \pm 0.28) \\
\end{array}$ & $\begin{array}{c}3.46 \\
( \pm 0.69)\end{array}$ & $\begin{array}{c}1.5 \\
( \pm 0.26) \\
\end{array}$ & $\begin{array}{c}2.42 \\
( \pm 0.33) \\
\end{array}$ & $\begin{array}{c}1.97 \\
( \pm 0.25)\end{array}$ & $\begin{array}{c}2.88 \\
( \pm 0.30)\end{array}$ & $\begin{array}{c}2.52 \\
( \pm 0.48)\end{array}$ & & $\begin{array}{c}0.14 \\
( \pm 0.09) \\
\end{array}$ & $\begin{array}{c}2.27 \\
( \pm 0.44) \\
\end{array}$ & 23.63 \\
\hline 6 & Chirocentrus dorab & $\begin{array}{c}2.69 \\
( \pm 0.46)\end{array}$ & $\begin{array}{c}2.7 \\
( \pm 0.29)\end{array}$ & $\begin{array}{c}2.79 \\
( \pm 0.23)\end{array}$ & $\begin{array}{c}3.94 \\
( \pm 0.62)\end{array}$ & $\begin{array}{c}3.22 \\
( \pm 0.51)\end{array}$ & $\begin{array}{c}2.63 \\
( \pm 0.31)\end{array}$ & $\begin{array}{c}1.6 \\
( \pm 0.24)\end{array}$ & $\begin{array}{c}1.89 \\
( \pm 0.22)\end{array}$ & $\begin{array}{c}1.72 \\
( \pm 0.33)\end{array}$ & & 0 & $\begin{array}{c}1 \\
( \pm 0.23)\end{array}$ & 24.18 \\
\hline 7 & Scomberoides lysan & $\begin{array}{c}0.16 \\
( \pm 0.09)\end{array}$ & 0 & 0 & $\begin{array}{c}0.36 \\
( \pm 0.20) \\
\end{array}$ & $\begin{array}{c}0.59 \\
( \pm 0.23)\end{array}$ & 0 & 0 & 0 & 0 & & 0 & 0 & 1.11 \\
\hline 8 & Sphyraena jello & 0 & $0.02( \pm 0.02)$ & 0 & $0.4( \pm 0.10)$ & 0 & $0.03( \pm 0.03)$ & 0 & 0 & 0 & & 0 & 0 & 0.45 \\
\hline 9 & Dussumieria acuta & $\begin{array}{c}3.05 \\
( \pm 0.53)\end{array}$ & $\begin{array}{c}2.77 \\
( \pm 0.43)\end{array}$ & $\begin{array}{c}2.05 \\
( \pm 0.23)\end{array}$ & $\begin{array}{c}1.09 \\
( \pm 0.22)\end{array}$ & $\begin{array}{c}4.29 \\
( \pm 1.00)\end{array}$ & $\begin{array}{c}3.09 \\
( \pm 0.48)\end{array}$ & $\begin{array}{c}1.92 \\
( \pm 0.21)\end{array}$ & $\begin{array}{c}2.08 \\
( \pm 0.25)\end{array}$ & $\begin{array}{c}1.41 \\
( \pm 0.55)\end{array}$ & & 0 & $\begin{array}{c}2.63 \\
( \pm 0.92)\end{array}$ & 24.38 \\
\hline \multicolumn{15}{|c|}{ Demersal fishes } \\
\hline 10 & Pampus argenteus & $\begin{array}{c}1.89 \\
(\square 0.16)\end{array}$ & $\begin{array}{c}1.25 \\
(\square 0.13)\end{array}$ & $\begin{array}{c}0.15 \\
(\square 0.04)\end{array}$ & $\begin{array}{c}0.93 \\
(\square 0.14)\end{array}$ & $\begin{array}{c}0.55 \\
(\square 0.09)\end{array}$ & $\begin{array}{c}0.01 \\
(\square 0.01)\end{array}$ & $\begin{array}{c}0.1 \\
(\square 0.03)\end{array}$ & $\begin{array}{c}0.05 \\
(\square 0.02)\end{array}$ & $\begin{array}{c}0.39 \\
(\square 0.08)\end{array}$ & \multirow{3}{*}{$\begin{array}{l}\text { No catch } \\
\text { due to } \\
\text { Monsoon } \\
\text { ban }\end{array}$} & $\begin{array}{c}9.76 \\
(\square 0.59)\end{array}$ & $\begin{array}{c}3.95 \\
(\square 0.28)\end{array}$ & 19.03 \\
\hline 11 & Parastromateus niger & $\begin{array}{c}0.01 \\
( \pm 0.01)\end{array}$ & 0 & 0 & 0 & $\begin{array}{c}0.02 \\
( \pm 0.02)\end{array}$ & 0 & 0 & 0 & 0 & & 0 & $\begin{array}{c}0.01 \\
( \pm 0.01)\end{array}$ & 0.04 \\
\hline 12 & Batrachocephalus mino & $\begin{array}{c}0.12 \\
( \pm 0.07)\end{array}$ & $\begin{array}{c}0 \\
( \pm 0.00)\end{array}$ & $\begin{array}{c}0.37 \\
( \pm 0.19)\end{array}$ & $\begin{array}{c}0.14 \\
( \pm 0.05)\end{array}$ & $\begin{array}{c}0.39 \\
( \pm 0.32)\end{array}$ & $\begin{array}{c}0 \\
( \pm 0.00)\end{array}$ & $\begin{array}{c}0.17 \\
( \pm 0.12)\end{array}$ & $\begin{array}{c}0.19 \\
( \pm 0.13)\end{array}$ & $\begin{array}{c}0.25 \\
( \pm 0.19)\end{array}$ & & 0 & $\begin{array}{c}0.27 \\
( \pm 0.15)\end{array}$ & 1.9 \\
\hline 13 & Muraenesox talabonoides & $1.22(\square 0.36)$ & 0 & 0 & $0.02(\square 0.02)$ & 0 & 0 & 0 & 0 & 0 & & 0 & 0 & 1.24 \\
\hline 14 & Johnius sp. & $\begin{array}{c}1.35 \\
( \pm 0.25) \\
\end{array}$ & $\begin{array}{c}0.33 \\
( \pm 0.13) \\
\end{array}$ & $\begin{array}{c}1.47 \\
( \pm 0.24) \\
\end{array}$ & $\begin{array}{c}2.99 \\
( \pm 0.42) \\
\end{array}$ & $\begin{array}{c}1.2 \\
( \pm 0.22)\end{array}$ & $\begin{array}{c}0.07 \\
( \pm 0.06) \\
\end{array}$ & $\begin{array}{c}0.3 \\
( \pm 0.17) \\
\end{array}$ & $\begin{array}{c}0.35 \\
( \pm 0.16)\end{array}$ & $\begin{array}{c}0.51 \\
( \pm 0.32)\end{array}$ & & 0 & $\begin{array}{c}1.26 \\
( \pm 0.28)\end{array}$ & 9.83 \\
\hline \multicolumn{2}{|c|}{ Total } & 28.97 & 27.61 & 24.05 & 22.32 & 22.08 & 25.33 & 17.48 & 22.84 & 26.09 & & 17.04 & 29.55 & 263.36 \\
\hline
\end{tabular}


Table.2 Details of species wise revenue (Rs.) of OBM gillnetters according to season

\begin{tabular}{|c|c|c|c|c|c|}
\hline \multirow{2}{*}{ Sr. No. } & \multirow{2}{*}{ Species } & \multicolumn{3}{|c|}{ Season (Revenue in Rs.) } & \multirow{2}{*}{$\begin{array}{c}\text { Total } \\
\text { (Revenue } \\
\text { Rs.) } \\
\end{array}$} \\
\hline & & Monsoon & Winter & Summer & \\
\hline \multicolumn{6}{|c|}{ Pelagic fishes } \\
\hline 1 & Ribbonfish Lepturacanthus savala & 226226 & 281190 & 264446 & 771862 \\
\hline 2 & Seerfish Scomberomorus commerson & 920 & 42504 & 8280 & 51704 \\
\hline 3 & Indian mackerel Rastrelilliger Kanagurta & 235710 & 463320 & 469485 & 1168515 \\
\hline 4 & Horse mackerel Megalalapsis cordyla & 4050 & 33102 & 10836 & 47988 \\
\hline 5 & Hilsa Hilsa toli & 83616 & 253440 & 217248 & 554304 \\
\hline 6 & Wolf herring Chirocentrus dorab & 11150 & 79575 & 59450 & 150175 \\
\hline 7 & Other Horse mackerel Scomberoides lysan & 0 & 3350 & 3550 & 6900 \\
\hline 8 & Barracuda Sphyraena jello & 0 & 4060 & 245 & 4305 \\
\hline 9 & Lesser sardine Dussumieria acuta & 8010 & 23500 & 28830 & 60340 \\
\hline \multicolumn{6}{|c|}{ Demersal fishes } \\
\hline 10 & Silver pomfret Pampus argenteus & 1100800 & 444800 & 69600 & 1615200 \\
\hline 11 & Black pomfret Parastromateus niger & 300 & 300 & 900 & 1500 \\
\hline 12 & Cat fishes Batrachocephalus mino & 3800 & 6400 & 7400 & 17600 \\
\hline 13 & Eel Muraenesox talabonoides & 0 & 11960 & 0 & 11960 \\
\hline \multirow[t]{2}{*}{14} & Croaker Johnius sp. & 18200 & 79200 & 23600 & 121000 \\
\hline & Total & 1692782 & 1726701 & 1163870 & 4583353 \\
\hline
\end{tabular}

Values in parenthesis are S.E of mean

(S.E. in some cases could not be estimated due to less number of landing values) 
Table.3 Economics of OBM gillnetters operated from Jaleshwar Coast, Veraval, during 2008-09

\begin{tabular}{|c|c|c|c|}
\hline & IteI & & $\begin{array}{l}\text { Amount } \\
\text { (Rs.) }\end{array}$ \\
\hline $\mathbf{A}$ & & apital cost & \\
\hline & 1 & Vessel & 74,700 \\
\hline & 2 & Engine (two cylinder) & 78,100 \\
\hline & 3 & Net 408 kg@Rs.380/-kg & $1,55,040$ \\
\hline & 4 & Rope117 kg@Rs.120/-kg & 14,040 \\
\hline & 5 & Indicator buoys 6 numbers. @ Rs.90 /-per buoy & 540 \\
\hline & 6 & Floats 316 numbers @ Rs.10/-per float & 31,60 \\
\hline & 7 & Stone sinker 1007 numbers @ Rs.7/-sinker & 7,049 \\
\hline & 8 & Anchor15 kg.@ Rs.50/-kg & 750 \\
\hline To & tal c & capital cost & $\mathbf{3 , 3 3 , 3 7 9}$ \\
\hline B & $\mathbf{V a}$ & ariable cost & \\
\hline & 1 & Fish holding vessel (tagara) 5 numbers @ Rs.50/- per tagara & 250 \\
\hline & 2 & Paint 2 litres@ @s.130/-per litre & 260 \\
\hline & 3 & Maintaince of gill net & 5,080 \\
\hline & 4 & Maintaince of engine(three times in a year) & 13,377 \\
\hline & 5 & License fee, @ Rs.505/-per year & 505 \\
\hline & 6 & $\begin{array}{l}\text { Kerosene total } 2131 \text { litres @ Rs.9/-per litre for } 1485 \text { litres and Rs. 35/-litre for } 645 \\
\text { litre }\end{array}$ & 35,940 \\
\hline & 7 & Oil 147 litres@ 150/- per litre & 22,050 \\
\hline & 8 & Petrol 291 litres @ Rs.50/-per litre & 14,550 \\
\hline & 9 & Crew salary & $15,556.41$ \\
\hline To & tal v & variable cost & $1,07568.41$ \\
\hline $\mathbf{C}$ & Tot & tal project cost $(A+B)$ & $\mathbf{1 , 4 0 , 9 4 7 . 4 1}$ \\
\hline $\mathbf{D}$ & Fix & xed cost & \\
\hline & & Depreciation & \\
\hline & 1 & Vessel and engine, at 10 percent & 15,280 \\
\hline & 2 & Net, at 25 per cent & 38,760 \\
\hline & 3 & Ropes, at 25 per cent & 3,510 \\
\hline & 4 & Indicator buoys, floats, sinkers and anchor at 20 per cent & $2,298.2$ \\
\hline To & tal fi & ixed cost & $5,9848.2$ \\
\hline $\mathbf{E}$ & & tal cost $(B+D)$ & $\mathbf{1 , 6 7 , 4 1 6 . 6 1}$ \\
\hline $\mathbf{F}$ & To & tal revenue (Rupees) & $\mathbf{1 , 5 2 , 7 7 8 . 4 3}$ \\
\hline $\mathbf{G}$ & Prc & ofit or Loss & $-14,638.2$ \\
\hline
\end{tabular}

\section{Variable cost}

Total variable cost was estimated by considering expenses on fuel, lubricant, wages, fees and repairing and maintenance. The estimated annual variable cost was Rs. 1,07,568.41 for OBM gillnetters. Expenditure on kerosene, oil and petrol had major share $68.47 \%$ in the total expenditure. Maintenance of net and engine contributed $17.16 \%$ for
OBM units respectively. Crew salary was found to be other major item of expenditure. Sharing system was followed to calculate the crew salary which contributed $14.46 \%$. Fees and other items such as fish holding utensils (tagara) and paint together formed $0.94 \%$ for OBM gillnetters. Silas et al. (1984) reported the variable cost at Rs. 66,337/- in the year 1981-82 whereas the variable cost by other workers ranged from Rs. 88,643 to Rs. 
1,13,837 (Sehara and Karbhari, 1989a) during the year 1986-87, Rs. $1,81,190$ to Rs. 3,33,200 (Rao and Pandey, 1990) in the year 1985-86 as compared to above studies the variable cost of the present studies were higher.

\section{Total project cost}

The estimated project cost for OBM gillnetter was Rs. 1, 40,947.41.

\section{Fixed cost}

Depreciation was included in the fixed cost. The fixed cost was estimated at Rs. 59,848.2 for OBM unit. Average life of 10 years was considered to work out the depreciation of vessels and engine whereas, with regard to net, the life expectancy was considered as four years. Depreciation of other items was calculated on the basis of expected life. Depreciation accounted four years for ropes and five years for indicator buoys, floats, sinkers and anchor. It was similar to the average life considered by Markad, (2004). Sehara and Karbhari (1989b) also considered the same life expectancy in case of vessel but considered expected life of 20 years for engine. The fixed cost reported by Sehara and Karbhari (1989b) ranged from Rs. 47,090 to Rs. 54,110 whereas Rs. 23,675 to Rs. 81,700 by Rao and Pandey (1990) at the Versova during 1985-86, Rs. 17,128 by Sathiadhas et al.. (1991) along the Tuticorin during 1987, Rs. 8,820 to Rs. 19,500 for plank built boats by Sathiadhas et al., (1993), Rs. 82,750 to Rs. 1,04,666 for $12 \mathrm{~m}$ vessels operated along the Tuticorin coast.

\section{Total expenditure and revenue}

The total expenditure i.e. total cost per year was calculated by adding the total fixed cost and total variable cost which came to Rs. $1,67,416.61$. Whereas total revenue was calculated at Rs. 1,52,778.43 for OBM gillnetters.

\section{Profit}

The annual loss of rupees $-14,638.2$ was incurred considering the initial investment in terms of capital cost at the end of first year however second year onwards the OBM gillnetters were profitable. Markad (2004) reported that the annual profit of the OBM gillnetter was Rs. 47,727 and for IBM gillnetters it was Rs. 1,26,758. Dave (2004) reported that the annual profit of the owner was Rs. 31,025.71 for OBM gillnetters. The result of the present study shows that fishermen of Jaleshwar village incurred annual loss rather than profits at the end of first year of fishing operation. However in the subsequent years, they achieved profits. The major problems faced by the Jaleshwar fishermen were lesser availability of fish, and higher fuel cost.

\section{References}

Anon. 2010. Gujarat Fisheries Statistics: 2006-2007. Commissioner of Fisheries, Gandhinagar.

Anon. 2014. Annual Report Published by Central Marine Fisheries Research Institute, Cochin 2010-2011.

Dave, G. and Shiyani, R.L. 2006. Economics of operation of different fishing vessels in relation to sustainability of coastal marine fish resources of Saurashtra. Fishing Chimes, 25(11): 40-43.

Koya, K.P.S. and Vivekanandan, E. 1992. Gill net fishery off Veraval during 1982-1990. Marine Fisheries Information Services, 116: 1-4.

Markad, T.A. 2004. Catch composition and economic analysis of gillnetters operating off Ratnagiri coast. A thesis submitted to Dr. B.S. Konkan Krishi 
Vidyapeeth, Dapoli, Mahrashtara. pp. 198.

Rao, P.S. and Pandey, S.K. 1990. Cost of production of various types of mechanised fishing at Versova landing center, Bombay. The Second Indian Fisheries Forum Proceeding, May 2731, 1990. Mangalore, India. pp. 357359.

Sathiadhas, R. and Panikkar, K.P.P. 1988. Socio-economics of small scale fishermen with emphasis on cost and earnings of traditional fishing units along Trivandrum coast, Kerala- A case study. Seafood Export J., 20: 21-37.

Sathiadhas, R., Benjamin, R. E. and Gurusamy, R. 1991. Technological options in the traditional marine fisheries sector and impact of motorization on the economics of gill net fishing along Tuticorin coast, Tamil Nadu. Seafood Export J., 23: 2636.

Sathiadhas, R., Panikkar, K.K.P. and Salini, K.P. 1993. Economics of traditional gill net fishing using wind energy along Tamil Nadu coast. In: V. C. George, V. Vijayan, M. D. Varghese, K. Radhalakshmi, S. N. Thomas and J.
Joseph (Editors), Proceedings of the National Workshop on Low Energy Fishing. Society of Fisheries Technologists, Matsyapuri P. O., Cochin. pp. 272-278.

Sehara, D.B.S. and Karbhari, J.P. 1989a. Economics of gill net fishing by OBM units at selected centers in Northwest coast. Marine Fisheries Information Services, 98: 1-8.

Sehara, D.B.S. and Karbhari, J.P. 1989b. Gill net fishing by mechanised boats at selected centres in Maharashtra and its profitability. Seafood Export J., 21: 1023.

Silas, E.G., Pillai, P.P., Jayaprakash, A.A. and Pillai, M.A. 1984. Focus on small scale fisheries: Drift gill net fishery off Cochin. 1981 and 1982. Marine Fisheries Information Services, 55: 112.

Somasekharan, K.V., Kizhakudan, J.K., and Kizhakudan, S.J. 2003. Sustainable Fisheries Development - Focus on Gujarat, CIFT, Cochin. pp. 1-10.

Thomas, S.N. and Hridayanathan, C. 2003. Catch analysis in small mesh gill nets. Indian J. Fish., 50(3): 387 -393.

\section{How to cite this article:}

Shabir Ahmad Dar, A.Y. Desai, A.N. Sayani and Jyoti Sharma. 2017. Economics of OBM Gill Netters along the Jaleshwar Coast, Veraval, Gujarat. Int.J.Curr.Microbiol.App.Sci. 6(5): 934941. doi: https://doi.org/10.20546/ijcmas.2017.605.103 